\title{
VAKAUMUKSEN POLKU MYÖS OHDAKKEINEN
}

\section{KARI E. TURUNEN (2004) Tunne-elämä. Atena.}

Kari.E.Turunen on kirjoittanut toistakymmentä ihmisen olemusta, ihmisen arvoitusta käsittelevää teosta, joista useimmat olen lukenut. Lähtökohtani tämän teoksen arviointiin ja pohdintaan ei siis välttämättä ole otollinen. Haen kirjasta vaistonomaisesti esiin kirjoittajan näkökulman muutoksia, katkoksia. Huomaan myös ajautuvani pohtimaan kirjoittajan maailmaa, miettimään miksi hän hahmottaa asiat tällä tapaa. Minun on siis vaikeata pitää erillään kirjoittajan aiempien teosten mieleeni tuottamista mieli- ja muistikuvista. Kykyni puhtaa- seen havaintoon on tältä osin vaurioitunut.

Yllä esittämäni muutaman lauseen rajaukset viestivät jo kirjan luonteesta. Siinä pohditaan aistimusten, havaintojen, ajattelun ja tunne-elämän muodostelmia ja suhteita. Kirjassa ei mainita, millaiselle kohderyhmälle se on tarkoitettu, ellei sitten kohderyhmän määrittelyksi hyväksytä takakannen lausetta "auttaa selvittämään tunteiden ongelmia ja näyttää tietä oman tunne-elämän kehittämiseen". Ja näinhän se on. Kirja soveltuu luettavaksi valistuneille aikuisille, jotka ajattelevat liikkuvasti eivätkä pidä syntyjen syvien pohtimista vastenmielisenä tai tarpeettomana puuhana.
Kirjassa käsitellään ihmisen sielunelämän näkökulmasta oikeastaan kaikkea mahdollista. Siinä pohditaan ihmisen ylempää ja alempaa luonnetta sekä pahan ongelmaa. Ihmiselämän voimakkaat perustunteet, häpeä, viha, pettymys ja kateus sekä kiintymys, tuska ja pelko saavat moniulotteisen, vivahteikkaan ja silti jotenkin julistavan tulkintansa. Kirjoittajan oma käsitys ja vakaumus asioista kuultaa voimakkaasti näkyviin ja asiat ja ongelmat tulevat myös - usein pelottavan helposti - ratkaistuksi.

Vakaumuksen polun ohdakkeisuus yleensä lisääntyy vakaumuksen voimistuessa, jonka vuoksi kirjoittajalla on näkemystensä puolustamisessa sar- 
kaa edessään. Kirjan ominaisluonnetta kuvaa mielestäni suhtautumiseni kaksijakoisuus. Arvostan teosta suuresti, toisaalta sen ehdottomuuden vuoksi suhtaudun siihen empien. Kirjoittajan rohkeus on kunnioitettavaa, toisaalta liiallinen rohkeus on houkkamaisuutta. Kirjassa on toisaalta itsestäänselvyyksiä täynnä, toisaalta kirjan 'totaliteetti' on erinomaisen lupaava, tunteiden maailman ymmärrystä täydellistävä. Uskonnollisten vertausten käyttö oli taitavaa ja toisaalta aivan liiallista; vaikka vertaukset rupesivatkin tympimään, saatiin niiden avulla kuitenkin näkyviin 'tunnepoliittisen olemuksemme' historiallinen luonne.

\section{RUISLEIVÄN SUOLA?}

Keille teos siis soveltuisi luettavaksi? Kirja on pohdiskeleva, jäsentävä, käsitteistöä tarjoava, julistava ja ehdoton. Monipuolisuutensa vuoksi sitä on arvioitava tutkimuksen ja käytännön ulottuvuuksissa, jotka taitavat samalla aika hyvin vastata Aikuiskasvatus-lehden lukijasegmenttejä.

(1)Tunteiden tutkimuksen psykologisten paradigmojen suunnasta teos vaikuttaa ensisi- jaisesti kiinnittyvän naturalistisen eli tunteiden biologista perustaa painottavien näkemysten varaan. Toissijaisesti teoksessa hyödynnetään tunteiden tutkimuksen yhteisöllistä näkökulmaa painottavaa konstruktivistista paradigmaa - vaatimukset ja yllykkeet ovat yhteisösidonnaisia. Keskeisten tunteiden nimeäminen ja niiden olemus jäsennetään mielestäni hyvin, joten tunteiden staattinen rakennekuvaus on mielestäni kohdallaan. Sitä vastoin tunteiden saattaminen toistensa yhteyteen tunnekäyttäytymisen dynamiikka siis - toteutetaan puolivillaisesti. Konkreettisten tapausesimerkkien käyttö samalla tapaa kuin Freud niitä teoksissaan käytti, olisi lisännyt uskottavuutta ja käyttökelpoisuutta.

(2) Aikuiskouluttajan käytännön työtä leimaa hektinen ihmissuhteiden paljous, verkostoituminen ja välittömän tuloksen korostaminen. Arjen paineessa ajattelun näkökulma uhkaa kaventua. Työssä oppien ei opita kaaosteorian perusteita. Myös ihmisen olemuksen, laadun ja luonteen pohdinta jää usein liian vähäiseksi. Vaikka olisi kuinka kiire, eikö maailmasta tule yksiulotteisen har- maa, jos ainoa huolenaihe on 'mistä saadaan ruisleipää'. Turusen kirja on ruisleivän suola; se sopii valistuneelle, ennakkoluulottomalle ja ihmisyyden mystiikasta kiinnostuneelle lukijalle pohdittavaksi.

\section{UUTTA TUNTEIDEN KERROKSISUUDESTA}

Vaan on vielä kolmas ulottuvuus, jossa kirjan painoarvoa ei ole punnittu. Erityisesti tunteiden voimataloudellinen puoli on ollut tutkimuksellisesti kovin vaikeasti haltuunotettavissa. Tunteiden tutkimus on - psykodynaamista näkökulmaa lukuun ottamatta - kärsinyt yksiulotteisuudesta niin käsitteistöissään kuin ihmiskäsityksissäänkin. Näin ollen tunteiden ajallinen kerrostuminen, jäsentyminen limittäin ja lomittain toisiinsa nähden, on puutteellisesti ymmärretty tutkimuskohde. Turusen teos on rohkea avaus tähän suuntaan, se tarjoaa uusia käsitteellisiä työvälineitä koeteltavaksi; se tarjoaa ihmistieteellisen oivaltamisen näkökulman, joka kannattaa ainakin tuntea.

\section{Juha Varila}

